\title{
Characterization of obstetric care developed in teaching hospitals in a capital of northeast Brazil
}

\author{
Caracterização da atenção obstétrica desenvolvida em hospitais de ensino de uma capital do nordeste brasileiro
}

Caracterización de la atención obstétrica desarrollada en la enseñanza de los hospitales de una capital del noreste de Brasil

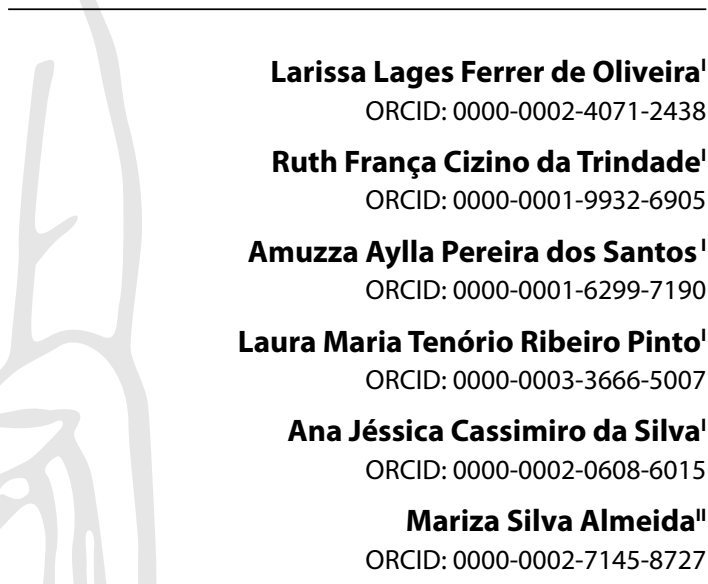

'Universidade Federal de Alagoas. Maceió, Alagoas, Brazil. "Universidade Federal da Bahia. Salvador, Bahia, Brazil.

How to cite this article: Oliveira LLFO, Trindade RFC, Santos AAP, Pinto LMTR, Silva AJC, Almeida MS. Characterization of obstetric care developed in teaching hospitals in a capital of northeast Brazil. Rev Bras Enferm. 2022;75(1):e20200896. https://doi.org/10.1590/0034-7167-2020-0896

Corresponding author: Amuzza Aylla Pereira dos Santos E-mail:amuzza1@hotmail.com

EDITOR IN CHIEF: Dulce Barbosa ASSOCIATE EDITOR: Ana Fátima Fernandes

Submission: $08-28-2020$

Approval: 04-02-2021

\begin{abstract}
Objective: to describe the obstetric care developed in teaching hospitals $(\mathrm{TH})$ in the city of Maceió-AL, intended for high-risk pregnancies. Methods: Retrospective cohort study performed between June and November 2018 with 291 women who received assistance with vaginal delivery, cesarean section, or abortion process in teaching hospitals selected as settings for this research. Data collection allowed the characterization of the interviewees as well as the assistance received and its relationship with obstetric violence. The analysis was performed using descriptive and analytical statistics with the aid of the Epi Info software (version 7.2.0.1) and measures that allowed the comparison of means and proportions. Results: All women reported at least one violent situation, contrary to recommendations based on scientific evidence. Conclusion: It becomes necessary to optimize professional training to deconstruct obstetric care based on medicalization and pathologization of pregnancy and strengthen science-based care.

Descriptors: Health Care; Nursing Care; Obstetrics; Violence Against Women; Teaching Hospitals.
\end{abstract}

\section{RESUMO}

Objetivo: Descrever a atenção obstétrica desenvolvida em hospitais de ensino (HE), em Maceió-AL, destinados à gestação de alto risco. Métodos: Estudo de coorte retrospectivo realizado entre os meses de junho e novembro de 2018 com 291 mulheres que receberam assistência ao parto vaginal, cesárea ou processo de abortamento nos hospitais escolas selecionadas como cenário desta pesquisa. A coleta dos dados permitiu a caracterização das entrevistadas bem como da assistência recebida e sua relação com a violência obstétrica. A análise foi realizada por meio da estatística descritiva e analítica com auxílio do software Epi Info (versão 7.2.0.1) e medidas que permitiram a comparação de médias e proporções. Resultados: Todas as mulheres referiram, no mínimo, uma situação de violência, contrariando recomendações baseadas em evidências científicas. Conclusão: Torna-se necessário otimizar a formação profissional para desconstrução da atenção obstétrica pautada na medicalização e patologização da gestação; e fortalecer o cuidado baseado na ciência.

Descritores: Atenção à Saúde; Cuidados de Enfermagem; Obstetrícia; Violência contra a Mulher; Hospitais de Ensino.

\section{RESUMEN}

Objetivo: Describir la atención obstétrica desarrollada en hospitales de enseñanza (HE), en Maceió-AL, destinados a embarazo de alto riesgo. Métodos: Estudio de cohorte retrospectivo realizado entre junio y noviembre de 2018 con 291 mujeres que recibieron asistencia al parto vaginal, cesárea o proceso de aborto en los HEs seleccionados. Recogida de datos permitió la caracterización de las entrevistadas, así como de la asistencia recibida y su relación con la violencia obstétrica. El análisis se realizó mediante estadística descriptiva y analítica con la ayuda del software Epi Info. (versión 7.2.0.1) y medidas que permitieron la comparación de medianas y proporciones. Resultados: Todas las mujeres refirieron, en lo mínimo, una situación de violencia, contrariando recomendaciones basadas en evidencias científicas. Conclusión: Es necesario optimizar la formación profesional para desconstrucción de la atención obstétrica pautada en la medicalización y patologización del embarazo; y fortalecer el cuidado basado en la ciencia.

Descriptores: Atención a la Salud; Cuidados de Enfermería; Obstetricia; Violencia contra la Mujer; Hospitales de Enseñanza. 


\section{INTRODUCTION}

The model of obstetric care has undergone essential changes throughout history. Childbirth care is considered a family event of female nature and was greatly influenced by urbanization and the founding of universities in the mid-nineteenth century. Since then, with the technical-scientific advances, birth assistance has become embattled by medicalization due to the intense pathologization of natural events in women's lives, compromising maternal and perinatal morbidity and mortality rates - indicators of care for this population ${ }^{(1)}$.

In this scenario, women's dissatisfaction with the (lack of) care they received promoted, in the 20th century, the emergence of the Movement for the Humanization of Childbirth. Thus designated, as it relates to the humanism movement that values the human being and his condition, which, thus confronting the theocentrism of the Middle Ages. In this sense, the qualification of assistance to the binomial based on the use of practices proven by science as beneficial and on the protagonism of the being cared for has become the objective of the movement, bringing together professionals from different areas around a series of claims in favor of this ideology (2).

Within the scope of the emergence of public policies linked to the ideology of qualification of obstetric and neonatal care, the document Assistance to Normal Childbirth: a Practical Guide, published in 1996 by the World Health Organization (WHO), has a representative symbology for the promotion of childbirth and healthy births, thus combating the high rates of maternal and neonatal morbidity and mortality, being the result of international debates based on scientific evidence. As an update, after almost two decades, the WHO published a compilation of recommendations entitled Intrapartum care for a positive childbirth experience, in order to contribute not only to safe assistance to the birth process but also to a positive experience focused on the role of women and the holistic approach based on human rights ${ }^{(3-4)}$.

Despite this effort, the alarming rate of cesarean sections in Brazil and the number of unnecessary interventions carried out by professionals who actively participate in the birth process and promoted discussions about a type of violence associated with obstetric care ${ }^{(5)}$. In this context, obstetric violence can then be understood as "any unnecessary act or intervention directed to the parturient woman or the neonate, practiced without the consent of the woman and/or in disrespect to her autonomy, physical or psychological integrity, going against her feelings, wishes and options"(6) or even as "the various forms of violence occurring in pregnancy care, childbirth, postpartum and abortion."(7).

It is important to emphasize that obstetric violence is supported by two other types of violence, gender and institutional. Gender violence is based on treatment based on a historical and social construction, in which women submit to patriarchal power, not being able to freely express their wishes and preferences; and as institutional violence, that which is practiced against women, through negligence or failure, in public or private institutions by professionals who should provide care, as well as prevent and/ or repair damage, and not promote them ${ }^{(8-9)}$.

In this paradoxical context generated by the confrontation between obstetric care and public policies, the reflection on the training of health professionals involved in women's health care becomes of great importance, especially in Teaching Hospitals (HE), in which training helps to understand the universe of the practice scenario, associating the curricular bases of courses in the health area, public, private, or formally affiliated higher education institutions ${ }^{(10-11)}$.

In view of this discussion relevant to the health team, it is worth highlighting the role of the obstetric nurse, which, according to current scientific evidence, is associated with a reduction in the number of unnecessary interventions during the care provided at work of childbirth and childbirth, in addition to the reception of the newborn and the perception by this woman of a positive experience of the parturition process ${ }^{(12)}$.

\section{OBJECTIVE}

Describe the obstetric care developed in teaching hospitals for high-risk pregnancy in Maceió, State of Alagoas (AL).

\section{METHODS}

\section{Ethical aspects}

In compliance with the legislation that regulates the conduct of scientific research involving human beings, after obtaining institutional authorizations from the teaching hospitals, the project of this research was forwarded for consideration to the Research Ethics Committee of the Universidade Federal de Alagoas through Plataforma Brasil, in order to confirm respect for ethical principles. It was approved. In the cases of acceptance of participation in the research, the participants or their parents/guardians read and signed the Termo de Consentimento Livre e Esclarecido (TCLE) (Informed Consent Form (ICF)) and, in the case of participants under 18 years old, signed the Termo de Assentimento Livre e Esclarecido (TALE), seeking to guarantee the understanding of the information and respect for the woman's autonomy. The documentation was then signed in two copies, one of them remaining with the participant/ guardian and the other with the researcher.

\section{Design, period, and place of study}

An observational epidemiological study that is characterized as a cohort and conducted in two teaching hospitals in the city of Maceió, State of Alagoas, planned to care for high-risk pregnant women, identified in this research TH-A and TH-B. The information was collected between June and November 2018. To guide the research methodology, we used the STROBE (Strengthening the Reporting of Observational Studies in Epidemiology) script of the Equator Network, suitable for cohort studies.

\section{Population; criteria of inclusion and exclusion}

We interviewed 291 women who received care related to vaginal delivery, cesarean section (antepartum or intrapartum), or the abortion process in the hospitals selected as the setting for this research. Inclusion criteria were women of any age group who agreed to participate in the research and who were physically and/or emotionally able to answer the questions in the data collection instrument. We excluded from the sample women under 18 years old unaccompanied by their parents or guardians due to the impossibility of signing the Informed Consent Form 
(ICF) and women who had experienced a delivery resulting from intrauterine fetal death (fetuses older than 20 weeks).

To establish the sample, we adopted the data pertinent to obstetric demand during 2017 in the teaching hospitals selected as data collection units as reference for this research. According to Chapter XV (pregnancy, labor, and puerperium) of the International Classification of Diseases and Health-Related Problems (ICD-10), these data refer to the modality of hospitalization. They are available in the Department of Informatics of the Unified Health System (DATASUS). The StatCalc statistical calculator was used to establish the sample adopting the following parameters: expected frequency of the event of $25 \%$ based on the study Brazilian Women and Gender in Public and Private Spaces ${ }^{(13)}$, a margin of error of $10 \%$, and degree of confidence of $90 \%$.

\section{Study protocol}

The collection of information occurred between June and November 2018 through a form developed in online and printed versions, allowing the sociodemographic and obstetric characterization of the interviewees and the analysis of the assistance provided to these women and its relationship with obstetric violence. The form was applied by nursing students from the Federal University of Alagoas, who were selected and trained throughout an extension project of the nursing school, providing the interaction between undergraduate and graduate (students).

In order to formalize the results of this study and compare them with those of other scientific publications on the subject, obstetric violence was defined as the dependent variable and as independent variables the socioeconomic and obstetric characteristics of the participants, such as age, municipality of residence, race/color, marital status, education, occupation, parity/obstetric past, and aspects related to the current pregnancy.

In this sense, to characterize obstetric violence, this research considered, in addition to the definitions brought previously, its relationship with the obstetric recommendations proposed by the WHO through the document entitled Intrapartum care for a positive childbirth experience, published in $2018^{(4)}$.

\section{Analysis of results and statistics}

After the collection stage, the data produced through these forms were entered into an Excel spreadsheet (Office Package 2016) and, subsequently, tabulated and analyzed according to descriptive and analytical statistics employing Epi Info software (version 7.2.0.1) with graphical elements produced in Excel. The comparison of means and proportions was used Analysis of Variance (ANOVA) and chi-square (x2), respectively. The Relative Risk (RR) was used as a risk measure, and, in all analyses, the significance level of a equal to 0.05 was considered the cutoff point.

\section{RESULTS}

The study interviewed women between 13 and 49 years old. There was a predominance of women aged 18 years or older; residents of the capital of the state of Alagoas; of mixed race; in a stable union; with between 10 and 12 years of education and belonging to the non-economically active population. The family income of the women interviewed ranged from 0 to 7 minimum wages, with a mean of $R \$ 1,141.50$ and a statistically significant difference compared to women who underwent cesarean sections ( $p=0.0361)$, who had higher income than the others.

Characterization of obstetric experience in hospitalization shows that $69.8 \%$ of the women interviewed had undergone a cesarean section, especially before labor, followed by others who had experienced vaginal delivery $(29.5 \%)$ and those hospitalized due to assistance in the abortion process $(0.7 \%)$.

As for parity, there was a predominance of women experiencing their first pregnancy (38.5\%); without experience of vaginal deliveries (51.5\%); had only undergone a cesarean section in their lives (45.7\%); and never experienced abortion (78\%). When questioned about the current pregnancy, $55.7 \%$ of puerperal women reported no planning for conception. Despite this data, $98.6 \%$ of the interviewees received prenatal care. From the point of view of analytical statistics, there was a significant association between the average number of pregnancies and women with no education ( $p=0.0000)$, widows $(p=0.0177)$, between 40 and 49 years old $(p=0.0000)$, and without planning the current pregnancy $(p=0.0299)$, which may portray the social vulnerability of this specific population.

It was observed that $67.6 \%$ of women had prenatal care only in Primary Health Care, having attended six consultations or more and started the follow-up until the 12th week of pregnancy. About the guidance given by health professionals who developed prenatal care, $47.7 \%$ of women verbalized not having received information about the maternity hospital of reference for childbirth care or complications, and $63.8 \%$ said they had not been oriented about the physiology of the birth process, nor obstetric care.

The analysis of the obstetric care model received by women in teaching hospitals found that all interviewees reported at least one situation of violence, among them: did not feel comfortable to present complaints or doubts; had hands, arms, or legs tied up; failed to understand the information they received; did not feel safe before the care received; did not get information about the procedures developed by health professionals; did not feel welcomed and/or supported; believe they did not have privacy respected; experienced non-consented procedures; did not stay with companions of their choice; were yelled at during the care; were asked to stop crying or screaming.

When comparing the obstetric care model developed in Teaching Hospitals A and B, we can infer that there was statistical significance only regarding the provision of information ( $p=$ $0.0294)$ and the feeling of safety during care $(p=0.0027)$, both with low strength of association due to the $\mathrm{RR}$ and $\mathrm{Cl}$ values. Thus, the outcomes occurred without significant differences concerning the place of hospitalization.

Regarding women who received assistance for vaginal delivery, it was observed that, during labor, $68.6 \%$ did not eat; $30.2 \%$ did not ingest liquids; $40.7 \%$ received synthetic oxytocin through venous access; $37.2 \%$ were not offered Non-Pharmacological Methods for Pain Relief (MNFAD); $33.7 \%$ were submitted to consecutive vaginal touches by different people; $27.9 \%$ underwent amniotomy; $10.5 \%$ were not free to wander and/or change position; $2.3 \%$ underwent trichotomy; and $2.3 \%$ underwent gastric lavage (Table 1). 
Table 1 - Statistical analysis of the variables pertinent to labor in relation to the type of delivery, Maceió, Alagoas, Brazil, 2018

\begin{tabular}{|c|c|c|c|c|c|c|}
\hline \multirow[b]{2}{*}{ Outcome } & \multicolumn{2}{|c|}{ Type of Childbirth } & \multicolumn{4}{|c|}{ Parameters } \\
\hline & $\begin{array}{c}\text { Vaginal } \\
\text { Delivery } \\
\text { (\%) }\end{array}$ & $\begin{array}{c}\text { C-section } \\
\text { intrapartium } \\
\text { (\%) }\end{array}$ & $\begin{array}{c}\text { Relative Risk } \\
\text { (RR) }\end{array}$ & $\begin{array}{c}\text { Confidence Interval } \\
(95 \%)\end{array}$ & Chi-square & $p$ value \\
\hline \multicolumn{7}{|c|}{ Wander and change of position } \\
\hline $\begin{array}{l}\text { Yes } \\
\text { No }\end{array}$ & $\begin{array}{l}89.53 \\
10.57\end{array}$ & $\begin{array}{l}61.29 \\
38.71\end{array}$ & 0.68 & $0.55|-| 0.84$ & 16.58 & $0.0000^{*}$ \\
\hline \multicolumn{7}{|c|}{ Liquid ingestion } \\
\hline $\begin{array}{l}\text { Yes } \\
\text { No }\end{array}$ & $\begin{array}{l}69.77 \\
30.23\end{array}$ & $\begin{array}{l}30.65 \\
69.35\end{array}$ & 0.43 & $0.29|-| 0.65$ & 22.15 & $0.0000^{*}$ \\
\hline \multicolumn{7}{|c|}{$\begin{array}{l}\text { Offering Non-Pharmacological Methods for Pain } \\
\text { Relief }\end{array}$} \\
\hline $\begin{array}{l}\text { Yes } \\
\text { No }\end{array}$ & $\begin{array}{l}62.79 \\
37.21\end{array}$ & $\begin{array}{l}20.97 \\
79.03\end{array}$ & 0.33 & $0.20|-| 0.55$ & 25.43 & $0.0000^{*}$ \\
\hline \multicolumn{7}{|c|}{ Receiving synthetic oxytocin } \\
\hline $\begin{array}{l}\text { Yes } \\
\text { No }\end{array}$ & $\begin{array}{l}40.70 \\
59.30\end{array}$ & $\begin{array}{l}17.74 \\
82.26\end{array}$ & 0.43 & $0.24|-| 0.78$ & 8.86 & $0.0029 *$ \\
\hline \multicolumn{7}{|c|}{ Undergoing Trichotomy } \\
\hline $\begin{array}{l}\text { Yes } \\
\text { No }\end{array}$ & $\begin{array}{c}2.33 \\
97.97\end{array}$ & $\begin{array}{l}12.90 \\
87.10\end{array}$ & 5.54 & $1.21|-| 25.23$ & 6.39 & $0.0114^{*}$ \\
\hline \multicolumn{7}{|c|}{ Gastric lavage } \\
\hline $\begin{array}{l}\text { Yes } \\
\text { No }\end{array}$ & $\begin{array}{c}2.33 \\
96.67\end{array}$ & $\begin{array}{c}8.06 \\
91.94\end{array}$ & 3.46 & $0.69|-| 17.29$ & 2.63 & 0.1302 \\
\hline \multicolumn{7}{|l|}{ Eating } \\
\hline $\begin{array}{l}\text { Yes } \\
\text { No }\end{array}$ & $\begin{array}{l}31.40 \\
68.60\end{array}$ & $\begin{array}{l}22.58 \\
77.42\end{array}$ & 0.71 & $0.41|-| 1.25$ & 1.39 & 0.2371 \\
\hline $\begin{array}{l}\text { Consecutiv } \\
\text { people }\end{array}$ & & & & & & \\
\hline $\begin{array}{l}\text { Yes } \\
\text { No }\end{array}$ & $\begin{array}{l}33.72 \\
66.28\end{array}$ & $\begin{array}{l}29.03 \\
70.97\end{array}$ & 0.86 & $0.52|-| 1.40$ & 0.36 & 0.5454 \\
\hline Undergoins & & & & & & \\
\hline $\begin{array}{l}\text { Yes } \\
\text { No }\end{array}$ & $\begin{array}{c}27.9 \\
72.09\end{array}$ & $\begin{array}{l}29.03 \\
70.97\end{array}$ & 1.04 & $0.62|-| 1.74$ & 0.02 & 0.8809 \\
\hline
\end{tabular}

In addition to women who experienced vaginal delivery, women who underwent intrapartum cesarean section also participated in labor. In these cases: $79 \%$ were not offered Non-Pharmacological Methods for Pain Relief; $77.4 \%$ of the respondents had not eat during this period; $69.4 \%$ did not ingest liquids; $38.7 \%$ were not free to wander and/or change position; $29 \%$ underwent trichotomy and $29 \%$ were submitted to consecutive vaginal touches by different people; $17.7 \%$ received synthetic oxytocin through venous access; $12.9 \%$ underwent trichotomy; and $8.1 \%$ underwent gastric lavage (Table 1).

While performing the statistical analysis of the outcomes compared with the type of childbirth, there is a statistically significant difference between women who experienced vaginal delivery and women who underwent cesarean section (both preceded by labor) regarding liquid ingestion ( $p=0.0000)$, wandering, and changing position freely $(p=0.0000)$, offering Non-Pharmacological Methods for Pain Relief $(p=0.0000)$ and administration of synthetic oxytocin ( $p=0.0029)$. Also, for women who experienced vaginal delivery, the risk of not ingesting liquids $(R R=0.43)$, not wandering, and changing position freely ( $R R=0.68)$, not using Non-Pharmacological Methods for Pain Relief $(R R=0.33)$, and receiving synthetic oxytocin $(R R=0.43)$ is lower than in those who underwent cesarean section (Table 1).

As for help during the expulsive period (vaginal delivery), $91.9 \%$ of the women gave birth in non-supine positions, mainly in the lithotomy/gynecological position (53.2\%) and semi-sitting position (45.6\%), besides having received pull induction (72.1\%). There were also, in smaller numbers, interviewees who underwent episiotomy (15.1\%) and the Kristeller Maneuver (5.8\%). When performing the statistical analysis of these data compared to the period of onset and number of prenatal visits, there was no statistically significant difference between the performance of the interventions mentioned above and prenatal characteristics. That may suggest that prenatal care initiated in the first trimester and with six consultations or more does not guarantee sufficient information for the prevention of unnecessary practices during obstetric care regarding women's empowerment.

Once submitted to cesarean section (antepartum or intrapartum), $4.3 \%$ of women did not obtain information about the reasons justifying the surgery. Among those informed, signs and/or symptoms related to pregnancy-specific hypertensive syndromes were used as an argument to undergo a cesarean section in a little less than half of the cases.

As for the assistance received by women and newborns in the postpartum period (vaginal deliveries and cesarean sections), in $56.4 \%$ of the assistance, there was no encouragement to breastfeed during the first hour of life of the newborn. $47.8 \%$ of the binomials did not establish skin-to-skin contact; In $39.8 \%$, there was no delayed clamping of the umbilical cord; in $38.8 \%$, the woman could not stay with her child; and in $33.6 \%$, the newborns were taken to the Intensive Care Unit (ICU) or Intermediate Care Unit (ICU) after birth (Table 2). 
Table 2 - Statistical analysis of the variables pertinent to postpartum in relation to the type of delivery, Maceió, Alagoas, Brazil, 2018

\begin{tabular}{|c|c|c|c|c|c|c|}
\hline \multirow[b]{2}{*}{ Outcome } & \multicolumn{2}{|c|}{ Type of delivery } & \multicolumn{3}{|c|}{ Parameters } & \multirow[b]{2}{*}{$p$ value } \\
\hline & $\begin{array}{l}\text { Vaginal } \\
\text { Delivery } \\
\text { (\%) }\end{array}$ & $\begin{array}{c}\text { C-section } \\
\text { intrapartium } \\
\text { (\%) }\end{array}$ & $\begin{array}{l}\text { Relative Risk } \\
\text { (RR) }\end{array}$ & $\begin{array}{c}\text { Confidence Interval } \\
(95 \%)\end{array}$ & Chi-square & \\
\hline \multicolumn{7}{|c|}{ Skin contact } \\
\hline $\begin{array}{l}\text { Yes } \\
\text { No }\end{array}$ & $\begin{array}{l}80.23 \\
19.77\end{array}$ & $\begin{array}{l}40.39 \\
59.61\end{array}$ & 0.50 & $0.41|-| 0.61$ & 38.42 & $0.0000^{*}$ \\
\hline \multicolumn{7}{|c|}{ Delayed cord clamping } \\
\hline $\begin{array}{l}\text { Yes } \\
\text { No }\end{array}$ & $\begin{array}{l}49.38 \\
50.62\end{array}$ & $\begin{array}{l}22.92 \\
77.08\end{array}$ & 0.46 & $0.30|-| 0.71$ & 13.52 & $0.0002^{*}$ \\
\hline \multicolumn{7}{|c|}{ Mother staying with baby } \\
\hline $\begin{array}{l}\text { Yes } \\
\text { No }\end{array}$ & $\begin{array}{l}75.58 \\
24.42\end{array}$ & $\begin{array}{l}55.17 \\
44.83\end{array}$ & 0.73 & $0.61|-| 0.86$ & 10.60 & $0.0011^{*}$ \\
\hline \multicolumn{7}{|c|}{$\begin{array}{l}\text { Encouraging breastfeeding in the first hour } \\
\text { of life }\end{array}$} \\
\hline $\begin{array}{l}\text { Yes } \\
\text { No }\end{array}$ & $\begin{array}{l}53.49 \\
46.51\end{array}$ & $\begin{array}{l}39.41 \\
60.59\end{array}$ & 0.73 & $0.56|-| 0.95$ & 4.86 & $0.0273^{*}$ \\
\hline \multicolumn{7}{|c|}{$\begin{array}{l}\text { Newborn referred to the Intensive Care Unit / } \\
\text { Intermediate Care Unit }\end{array}$} \\
\hline $\begin{array}{l}\text { Yes } \\
\text { No }\end{array}$ & $\begin{array}{l}29.07 \\
70.93\end{array}$ & $\begin{array}{l}35.47 \\
64.53\end{array}$ & 1.22 & $0.83|-| 1.78$ & 1.10 & 0.2922 \\
\hline
\end{tabular}

Regarding statistical analysis, there was no statistically significant difference between newborns referred to the Intensive Care Unit or Intermediate Care Unit when comparing types of birth; however, this difference was significant when assessed from the perspective of good neonatal practices. The data show that among binomials who had experienced vaginal delivery, there was a lower risk of no delayed cord clamping ( $R R=0.46)$, no encouragement of breastfeeding in the newborn's first hour of life $(R R=0.73)$, no skin-to-skin contact $(R R=0.50)$ and that the newborn did not remain with the mother after birth (RR = 0.73) (Table 2).

\section{DISCUSSION}

During the birth process, the woman experiences emotions such as fear of complications, anxiety for her child's birth, and the loneliness experienced in the environment where she lives ${ }^{(14)}$. Therefore, to ensure a welcoming experience, she should be informed about the obstetric care procedures to understand what is being said and feel safe in the context in which she is inserted.

In addition to the failure to provide information, the assessment of other aspects directly related to the assistance received in the teaching hospitals demonstrates some situations characterized as obstetric violence, to the extent that they disrespect scientific guidelines for ensuring the quality of care, such as the impossibility of the presence of a companion chosen by the parturient, the performance of procedures without the permission of the woman, health professionals yelling to communicate with women, and the absence of welcoming during the hospital experience.

Regarding the absence of a companion of the woman's choice, since 2005, Law No. 11.108 guarantees a companion's presence (indicated by the woman) during labor, delivery, and immediate postpartum in the context of SUS ${ }^{(15)}$. Not ensuring this access to women equals not providing information about their rights and institutional violence since the service vetoes what is established by law.
The benefits of the participation of a companion during labor and birth have been widely reported in national and international literature, among which are: greater overall woman satisfaction with the experience of the birth process (promoting comfort and safety), reduced use of drugs for pain relief and reduction in the rate of interventions such as cesarean section and episiotomy, and better Apgar scores for babies at birth ${ }^{(15)}$.

Respectful care in obstetrics is a service organized for/provided to all women to preserve their dignity, privacy, and confidentiality and free them from mistreatment to allow informed choice besides the reception/support during labor and delivery ${ }^{(16)}$. Opposite to this recommendation, some women in this study did not feel safe about the assistance they received or welcomed by the hospital's health professionals where they were hospitalized.

It is noteworthy that the issue of reception in health has been discussed for quite some time through relevant public policies, in which it is argued that this is an attitude capable of building relationships of trust, commitment, and bond between health workers and users $^{(17)}$. A positive aspect observed is that, among the women who felt welcomed and supported during hospitalization, the health professional belonged to the nursing team in more than half of the cases.

In line with this data, a study conducted in a Prenatal/Partum/ Postpartum (PPP) unit of a teaching hospital in Mato Grosso(18), between the years 2014 and 2016, intending to analyze the care provided after the insertion of obstetric nurses, found that the practice of these professionals is associated with the principles of humanization of labor and birth, promoting the appreciation/ qualification of their work process.

In the search for change in the current obstetric model and consequent qualification of assistance to the birth process, the role of obstetric nursing is highlighted. According to Reis et al., "The training of the nurse-midwife involves skills and competencies that enable the provision of comprehensive care, respecting childbirth as a physiological process, with a positive impact on maternal and child health"(19), which conveys safety and comfort 
to women; thus, it rescues their self-confidence; and strengthens their ability to give birth.

In this sense, framed in the definition of midwife according to the Pan American Health Organization (PAHO), the obstetric nurse is characterized by the uniqueness in the provision of care, which provides the woman with harm-free care, providing the promotion and prevention of injuries, focused on self-care, respecting human dignity and enjoying full human rights, empowering them in the choices, so that the attempts of harmful cultural practices do not take away their protagonism in the event of pregnancy and make them strengthened in the choices in a way that pregnancy can be considered a normal life event ${ }^{(20)}$.

Concerning labor care for women who have experienced vaginal delivery or intrapartum cesarean section, there were practices considered unnecessary from the perspective of evidence-based care such as trichotomy, deprivation of wandering and change of position, as well as successive vaginal touches performed by different people and failing to provide Non-Pharmacological Methods for Pain Relief, reinforcing the medicalization of labor and birth care ${ }^{(21)}$.

In contrast to this study data, current research recommends that women drink liquids during labor, and those without risk factors should eat, not undergo routine trichotomy, and be encouraged to wander and adopt upright postures. They should be submitted to vaginal touches at least four hours apart, be offered relaxation techniques for pain relief, according to their preference (music therapy, breathing technique, meditation, and/or massage), and not be subjected to amniotomy and administration of synthetic oxytocin to shorten the duration of labor ${ }^{(22)}$.

In this perspective, about assistance to vaginal delivery/expulsive period, practices such as induction of pulling, episiotomy, and Kristeller Maneuver were scored by the women interviewed as offered by health professionals. However, during the expulsive period, women should be encouraged and supported to follow their impulse to conduct their pulls and should not be submitted to a routine episiotomy or the Kristeller Maneuver to justify facilitating birth ${ }^{(23)}$.

Besides adopting such practices, almost all the women interviewed gave birth in the supine position (lithotomy/gynecological position, semi-sitting, or lateralization). According to scientific evidence, walking and adopting upright positions during the birth process have advantages such as reducing the first and second stages of labor (dilation and expulsion); reducing the need for analgesia by reducing stress and pain; reducing the incidence of fetal distress, and promoting better conditions for the newborn, and encouraging the woman to participate actively in the birth of her child ${ }^{(22)}$. Thus, women should be encouraged to move and adopt positions of their choice during the birth process.

When analyzing the results pertinent to hospitalization regarding the route of birth, most of the interviewees underwent cesarean section (antepartum or intrapartum), and this corresponds to a cesarean rate of $70.2 \%$ in this study. Such data represents a significant public health problem and characterizes as obstetric violence. It carries risks to the mother-child population since it is much higher than what is stipulated by the WHO, showing itself questionable about its emergency character ${ }^{(23)}$. Besides, the nonadherence to good obstetric and neonatal practices configures a risk for women who have experienced a vaginal delivery.
The situation is even more alarming because the maternity hospitals participating in this research are institutions that train health professionals and should be concerned with the learning process based on scientific evidence, referring to surgery only women with objective indications. Deconstructing the perception that the woman's body is imperfect (the basis of the medicalization of care) and that knowledge comes from repetition of techniques might to contribute to a critical thinking aimed at reducing the cesarean rate.

Another important issue concerns the fact that, in the study, there were women who were not informed about the reasons why they needed surgery, which goes entirely against the principles of humanization of care, since communicating to the patient the procedures performed on her body should be the first activity performed by the health professionals, even before developing the technique they propose.

As for the analysis of data related to assistance to the binomial in the postpartum period, adherence to care such as skin-to-skin contact, delayed cord clamping, and encouragement of breastfeeding in the first hour of life is compromised. Although such care is proven beneficial, it is not widely practiced, even in cases when babies are not referred to the Intensive Care Unit/Intermediate Care Unit, which is in line with the study "Birth in Brazil," which showed approximate percentages for non-adherence to such practices in the Northeast Region ${ }^{(24)}$. Thus, one can infer obstetric violence under its neonatal aspect since such professional practice compromises the benefits of respect for the golden hour for maternal and child health.

\section{Study limitations}

The study's limitations were related to the approach to the theme around which there is already some embarrassment. Some participants were afraid to answer the interview form and did not want to participate in the study because of fear. This episode caused changes in the deadline, making it challenging to complete the study.

\section{Contributions to the fields of Nursing, Health or Public Policy}

This study becomes relevant given the scientific evidence, in current national and international publications, of a type of violence linked to the unsatisfactory quality of obstetric care. This work seeks to characterize the model of care developed in institutions for the training of health professionals, promoting reflection about the learning process in such settings. The information produced may offer subsidies to provide the planning of strategies committed to obstetric care, aiming to contribute to assistance in line with the guiding principles of the Unified Health System (SUS).

\section{CONCLUSION}

Given what we discussed, identifying that all women interviewed had suffered at least one form of obstetric violence requires attention from those who propose to assist. Thus, it becomes necessary a directed look at optimizing professional training in these teaching hospitals, both concerning new health professionals and those already trained (continuing education). This is important to ensure the development of care based on safety by considering scientific 
evidence and the protagonism of women and newborns (individuality and integrality), deconstructing models based on medicalization and pathologization of pregnancy, highlighting, in this paradigm shift, the figure of the obstetric nurse and the midwife.

\section{SUPPLEMENTARY MATERIAL}

Oliveira LLF de. Caracterização do cuidado obstétrico em hospitais de ensino de alto risco: um estudo de coorte retrospectivo.
2019. 70 f. Dissertação (Mestrado Enfermagem) - Escola de Enfermagem e Farmácia, Programa de Pós-graduação em Enfermagem, Universidade Federal de Alagoas, Maceió, 2019. Available from: http://www.repositorio.ufal.br/handle/riufal/5545.

\section{FUNDING}

This research was supported by the Research Support Foundation of the State of Alagoas (FAPEAL).

\section{REFERENCES}

1. Carlo WA, Travers CP. Maternal and neonatal mortality: time to act. J Pediatr. 2016; 92(6):543-5. https://doi.org/10.1016/j.jped.2016.08.001

2. D'aquino LS. The humanization of childbirth movement as a social movement and its similarities with the recent protests that have taken the world. Rev Dir Soc Pol Públicas [Internet]. 2016 [cited 2019 Apr 12]; 3(1):46-58. Available from: http://www.unifafibe.com.br/revista/ index.php/direitos-sociais-politicas-pub/article/view/119/pdf

3. Carvalho SR, Rodrigues CO, Costa FD, Andrade HS. Medicalização: uma crítica (im)pertinente? Introdução. Physis Rev Saúde Coletiva. 2015; 25(4):1251-69. https://doi.org/10.1590/S0103-73312015000400011

4. World Health Organization (WHO). WHO recommendations: intrapartum care for a positive childbirth experience. Geneva: WHO [Internet]. 2018 [cited 2019 Apr 12]. Available from: https://www.who.int/publications/i/item/9789241550215

5. Zanardo GLP, Uribe MC, Nadal AHR, Habigzang LF. Obstetrical violence in Brazil: a narrative review. Psicol Soc. 2017;26:e155043. https://doi. org/10.1590/1807-0310/2017v29155043

6. Oliveira VJ, Penna CMM. Discussing obstetric violence through the voices of women and health professionals. Texto Contexto Enferm. 2017;26(2):e06500015. https://doi.org/10.1590/0104-07072017006500015

7. Diniz SG, Salgado HO, Andrezzo HFA, Carvalho PGC, Carvalho PCA, Aguiar CA, Niy DY. Abuse and disrespect in childbirth care as a public health issue in Brazil: origins, definitions, impacts on maternal health, and proposals for its prevention. J Hum Growth Dev. 2015;25(3):377-84. https://doi. org/10.7322/jhgd.106080

8. Marrero L, Brüggemann OM. Institutional violence during the parturition process in Brazil: integrative review. Rev Bras Enferm. 2018;71(3):1152-61. https://doi.org/10.1590/0034-7167-2017-0238

9. Chai CG, Santos JP, Chaves DG. [Institutional violence against women: the judiciary power, from pretenso protector to agressor effective]. Rev Eletrôn Direito UFSM. 2018;13(2):640-65. https://doi.org/10.5902/1981369429538 Portuguese

10. Araújo KM, Leta J. Federal university hospitals and their institutional missions in the past and present. Hist Cienc Saude-Manguinhos. 2014;21(4):1261-81. https://doi.org/10.1590/S0104-59702014005000022

11. Nogueira DL, Lira GV, Albuquerque IMN, Linhares MSC. Evaluation of Brazil's Teaching Hospitals: a systematic review. Rev Bras Educ Med. 2015;39(1):151-8. https://doi.org/10.1590/1981-52712015v39n1e00772014

12. Andrade LO, Felix ESP, Souza FS, Gomes LOS, Boerys RNSO. Práticas dos profissionais de enfermagem diante do parto humanizado. Rev Enferm UFPE.2017;11(Supl. 6):2576-85. https://doi.org/10.5205/reuol.9799-86079-1-RV.1106sup201712

13. Sena LM, Tesser CD. Obstetric violence in Brazil and cyberactivism of mothers: report of two experiences. Interface Comun Saúde Educ. 2017;21(60):209-20. https://doi.org/10.1590/1807-57622015.0896

14. Rodrigues FAC, Lira SVG, Magalhães PH, Freitas ALV, Mitros MS, Almeida PC. Violence obstetric in the parturition process in maternities linked to the Stork Network. Reprod Clim . 2017;32(2):78-84. https://doi.org/10.1016/j.recli.2016.12.001

15. Souza SRRK, Gualda DMR. The experience of women and their coaches with childbirth in a public maternity hospital. Texto Contexto Enferm. 2016;25(1):e4080014. https://doi.org/10.1590/0104-0707201600004080014

16. Pereira SB, Diaz CMG, Backes MTS, Ferreira CLL, Backes DS. Good practices of labor and birth care from the perspective of health professionals. Rev Bras Enferm. 2018;71(Suppl 3):1313-9. https://doi.org/10.1590/0034-7167-2016-0661

17. Martins CP, Luzio CA. HumanizaSUS policy: anchoring a ship in space. Interface (Botucatu). 2017;21(60):13-22. https://doi. org/10.1590/1807-57622015.0614

18. Ruschi GEC, Zandonade E, Miranda AE, Antônio FF. Determinantes da qualidade do pré-natal na Atenção Básica: o papel do Apoio Matricial em Saúde da Mulher. Cad Saúde Colet. 2018;26(2):131-9. https://doi.org/10.1590/1414-462×201800020229

19. Reis TR, Zamberlan C, Quadros JS, Grasel JT, Moro, ASS. Obstetric Nurses: contributions to the objectives of the Millennium Development Goals. Rev Gaúcha Enferm. 2015;36(esp):94-101. https://doi.org/10.1590/1983-1447.2015.esp.57393

20. Organização Panamericana de Saúde (OPAS). Conjunto de ferramentas para o fortalecimento da obstetrícia. Montevidéu: CLAP/SMR, 2014. 
21. Andrade PON, Silva JQP, Diniz CMM, Caminha MFC. Factors associated with obstetric abuse in vaginal birth care at a high-complexity maternity unit in Recife, Pernambuco. Rev Bras Saúde Matern Infant. 2016;16(1):29-37. https://doi.org/10.1590/1806-93042016000100004

22. Gupta JK, Sood A, Hofmeyr GJ, Vogel JP. Position in the second stage of labour for women without epidural anaesthesia: review. Cochrane Database Syst Rev. 2017;5(5):CD002006. https://doi.org/10.1002/14651858.CD002006.pub4

23. Oliveira RR, Melo EC, Novaes ES, Ferracioli PLRV, Mathias TAF. Factors associated to caesarean delivery in public and private health care systems. Rev Esc Enferm USP. 2016;50(5):733-40. https://doi.org/10.1590/s0080-623420160000600004

24. Moreira MEL, Gama SGN, Pereira APE, Silva AAM, Lansky S, Pineiro RS, et al. Clinical practices in the hospital care of healthy newborn infant in Brazil. Cad Saúde Pública. 2014;30(Suppl 1):S128-S139. https://doi.org/10.1590/0102-311X00145213 